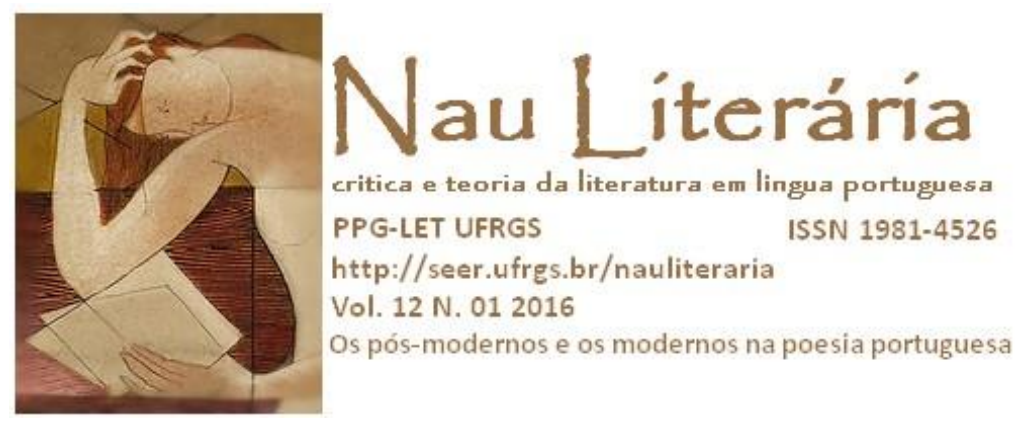

\title{
HERBERTO HELDER E A POÉTICA PÓS-MODERNA
}

\author{
Maria da Glória Bordini ${ }^{1}$
}

\begin{abstract}
RESUMO: Por meio da análise do poema IV de Do Mundo, buscam-se depreender os princípios de uma poética pós-moderna em Herberto Helder. A caracterização da pós-modernidade na poesia portuguesa é pautada pelas contribuições de Linda Hutcheon sobre ex-centricidade, e de Fernando J.P. Martinho e de Fernando Pinto do Amaral sobre sua trajetória histórica a partir dos anos 1960.
\end{abstract}

PALAVRAS-CHAVE: Herberto Helder; Pós-modernidade; Poética.

\begin{abstract}
Analyzing the poem IV in Do Mundo, the principles of a postmodern poetics in Herbert Helder are searched. Linda Hutcheon's notion of ex-centricity subsides the characterization of post-modern Portuguese poetry, based on the contributions of Fernando J. P. Martinho and Fernando Pinto do Amaral about its historical trajectory from de 60 s onwards.
\end{abstract}

KEYWORDS: Herberto Helder; Post-modernity; Poetics.

O pensamento pós-moderno refuta definições estáticas e a naturalização de conceitos, contestando os discursos de centralização dos quais contraditoriamente depende (cf. HUTCHEON, 1991, p. 87). No plano da produção poética, a concepção do que significa o ato poético e seu efeito sobre o leitor hoje varia conforme a posição de cada poeta, mergulhado em sua cultura e herdeiro de uma tradição literária antes delimitada pelas fronteiras nacionais, mas agora deslizante para outras nacionalidades, raças, etnias e gêneros. A situação de

\footnotetext{
${ }^{1}$ Doutora em Letras/PUCRS. Docente convidada da UFRGS. Pesquisadora do CNPq.
} 
Portugal, no contexto da poesia contemporânea, projetada numa perspectiva global, apresenta a mesma instabilidade de caracterização.

Se não há conceitos totalizantes, se, do ponto de vista das teorias correntes, o poético já não reside na estruturação linguística do texto, nem nas suas projeções imaginárias impregnadas do inefável, não se resolve pelo desvio de linguagem ou pela opacidade da linguagem (como queria Sartre), não partilha do sagrado e da totalidade original, não é a "morada do Ser" heideggeriana, o que resta é perscrutar o que dizem os poetas. Todavia, eles já não se comportam como os modernistas, que pontificavam do alto de seus programas e estabeleciam regras até para a ruptura do convencional. Não é que recusem o legado da poesia moderna, pois temas, procedimentos técnicos, posições estéticas desta reaparecem seguidamente em sua produção. O que os distingue é uma aproximação maior com o público, uma abertura à transparência de atitudes, revelando incertezas e insuficiências, uma tendência ao subjetivismo e à autoexposição, paradoxalmente mais fictícia do que autobiográfica.

Localizando a poesia pós-moderna no espectro histórico da poesia portuguesa, Fernando J. P. Martinho adverte que:

\footnotetext{
entre o momento em que se torna mais nítida, nos anos 70, a despedida da modernidade e o presente momento há um lapso de tempo que corresponde mais ou menos a um quarto de século. Isto ajuda a explicar a crescente serenidade com que é encarada a relação com a tradição, da mais recuada à de mais recente constituição. (MARTINHO, online)
}

Longe de um posicionamento anistórico, a relação dos pós-modernos portugueses mais recentes com o legado da modernidade se torna pacífico, como afirma Martinho. Todavia, também se poderia considerar que nesse interregno um poeta afrontou tudo o que se fizera antes, reinstituindo temas e formas a partir de fora dos sistemas vigentes e ombreou-se em potência criativa e originalidade a Fernando Pessoa, desafiando seus pares e seus leitores a decifrá-lo em sua dissidência.

Herberto Helder, madeirense nascido em 1930 e falecido em 2015, foi de tudo um pouco: jornalista, repórter de guerra, bibliotecário, tradutor, publicitário e apresentador da Rádio e Televisão portuguesas, além de operário de forjas, auxiliar de cozinha, policopista, empacotador, carregador. Em suas errâncias por Lisboa, Coimbra, Paris, Londres, pela Bélgica, Holanda, Dinamarca e Angola (veja-se a biografia de Maria de Fátima Marinho em MARINHO, 1982), adquire todas as peculiaridades do ex-cêntrico postulado por Linda Hutcheon como elemento-chave do pós-moderno: valorização das margens, do ethos local, do 
aberrante, do heterogêneo, da deshierarquização, da dispersão. Há nele, a par desse daimon perturbador, um espírito assombrado pelo sublime, cabendo lembrar que "a diferença pósmoderna é sempre plural e provisória" (HUTCHEON, 1991, p. 94), o que torna sua obra, desde o afamado Colher na boca, de 1961, quase indecidível, como se pode observar em Photomaton \& Vox, de 1979, e mais ainda em Do Mundo, de 1994.

Fernando Pinto do Amaral, ao estudar a poesia moderna e pós-moderna em Portugal, situa os anos 1960 como um de seus momentos-chave, citando apenas de passagem "o irreprimível e poderoso fluxo imagético pós-surrealista de Herberto Helder” (AMARAL, 1991, p. 47). O privilégio à textualidade, a "rarefação do sentido", o adensamento do significante, o experimentalismo típicos da Poesia-61, segundo ele, teriam se esgotado nos anos 70 em favor de uma comunicabilidade neoconfessional, de uma atenção ao cotidiano, de uma vontade de realismo, de uma ênfase à experiência vivida, emocional, de um resgate do sentido (idem, p. 48-49) que persistiriam para além do século XX.

Nessa trajetória, a poesia de Helder, insubmissa, segue um rumo divergente, recolhendo lascas de estéticas do passado, da passionalidade romântica, da recusa modernista aos cânones de toda ordem, da desconexão onírica dos surrealistas, para criar um universo extremamente pessoal, hermético e demiúrgico, no qual o ato poético emula as origens para além do tempo e do espaço convencionais.

Apesar de fugir aos traços normalmente aceitos como característicos da poesia portuguesa pós-moderna, Herberto Helder é um homem deste tempo de proliferação de imagens, de não totalização, de incertezas sobre a possibilidade da representação nas artes e na literatura, de dúvida quanto à autoridade das ciências e do próprio artista, de fechamento no eu, de deriva incessante. Entretanto, sua obra atesta constantemente a potência criadora da poesia, seu enraizamento nas entranhas deste planeta, refutando a sua irrelevância numa época enredada em discursos sobre discursos, de reflexos sobre reflexos, de irreferencialidade, como se pode constatar no poema IV de Do mundo (1991-1994) ${ }^{2}$ :

\footnotetext{
Este que chegou aо seu poema pelo mais alto que os poemas têm

chegou ao sítio de acabar com o mundo: não o quero

para o enlevo, o erro, disse,

quero-o para a estrela plenária que há nalguns sítios de alguns poemas

abruptos, sem autoria.
}

\footnotetext{
${ }^{2}$ HELDER, Herberto. 2009. p. 141-143.
} 
Num ritmo que se exalta no primeiro verso e declina no segundo, acabando numa negação interrompida, o poema introduz uma personagem e uma noção de exacerbada altura de criação, para recusar-lhe duas funções: o enlevo e o erro. A poesia não é feita para elevar ou para ser mal compreendida. O sujeito lírico reporta a fala dessa personagem poeta no inesperado "disse", para retomar a elevação em "estrela plenária", ligando o quarto verso ao primeiro, com seu "alto", mas reforçando outra vez a negatividade do poema, transparente no segundo verso em "acabar com o mundo", e no quinto, em "sem autoria", situando a "estrela plenária" em sítios "abruptos". "Mundo" rima assonantemente com "abruptos", mas rompe sonoramente a eufonia das nasais de um pelos dígrafos de outro. Já no início do poema, instala-se a contradição das imagens entre altura poética, estelar, e destruição, do poeta e do mundo, como se a poesia tivesse a potência de um choque cósmico.

\section{Esteve ali a descobrir a ríspida maneira}

daquilo:

plutónio, o abismo.

A luz trabalhava à rapidez do esplendor.

Os pregos vivos pela cabeça dentro, eu sei.

Vaso feito ao vivo, soprado quente, disse, eu sei.

O sujeito poético reporta a voz do outro, com a reiteração de seu saber, que se envolve em consoantes rascantes e duras, fricativas e labiodentais, mais alguns encontros consonantais e um dígrafo. Há uma oscilação nessa "rispidez", representada pelos "ll" e "ss", que dão fluência à afirmação de que "a luz trabalhava à rapidez do esplendor". A poesia, associada à imagem da luz, viaja numa velocidade insuportável em direção ao "plutônio" e "abismo", palavras isoladas no mesmo verso e em entoação descendente, indicando a profundidade em que a mente trabalha e preparando para os "pregos" - conotação da familiar imagem da coroa de espinhos - e para o "vaso" soprado quente - lembrança de que o vidro só toma forma quando incandescente -, que indiciam a dor do poetar e sua extrema dificuldade.

O sistema do som no recôndito do poema para sempre,

poema incólume, de

música e

magnificação. 
Onde se fica para o delírio, na parte

alta, devorada pelo ouro, a parte inóspita.

Frequentado também pelo mais simples:

quantidade e frescura, exemplo:

as frutas embebedam.

A próxima fase da estrofe inicia com o eco dos sons nasais fechados, levados adiante pelas sibilantes, iconizando a ideia de sistema sonoro como fundo do poema. Logo se altera com a repetição de "poema" adjetivado de "incólume", como se a salvo dentro de sua sonoridade, que é iterada por "música", mas se amplia como sob uma lente de aumento, o som transformado em coisa cuja dimensão pode ser majorada. De imediato da sonoridade magnificada se passa para o imagético, remetendo aos versos iniciais, quanto à altura e à luz, que alteram a racionalidade, e aos da fase seguinte, quanto à explosão de dor e de novo de luz - "plutônio" evoca a bomba atômica -, ante a hostilidade da poesia. Todavia, o poema se curva do cósmico para o cotidiano, para as "frutas" que se oferecem profusamente em sua simplicidade, em sua "frescura" - ligadas pela repetição do encontro consonantal -, e contêm o mesmo ingrediente do "abismo", aquele que leva à embriaguês, parente do "delírio".

Alguém disse: a estrela absoluta entrou pela tua suavidade.

Travessa a travessa de osso - porque eras virgem - e transmudou-te.

Filho.

A boca a doer com o bafo e o hausto.

Queimado onde se fecha a carne, ou aberto pode

dizer-se

como buraco de matéria materna.

Áspera sacaria em cima:

sacos brilhando, sacos de sangue amarrado.

O dizer continua a chamar a voz de um outro, desta vez mais indeterminado, qual profeta a explicar o inominável: a posse do sujeito poético pela "estrela absoluta". Estar possuído pela poesia é um ato de violação, impregna osso por osso - a repetição de "travessa a travessa" recorda a imagem de martírio dos pregos na cabeça - e transforma o interlocutor em poeta, que a seu turno também experimenta o tormento do dizer: "bafo" e "hausto" remetem ao respirar, base da voz.

A repetição de "kk" em "queimado" e "carne", e de "bb" em "aberto" e "buraco" cria uma vizinhança semântica entre os vocábulos, associa as imagens do parto, em "matéria 
materna", com as de uma ferida cauterizada, embrulhando tudo na aspereza do revestimento dos sacos, metonímia de corpo ferido em "sacos de sangue amarrado". Ser tomado pela poesia é ao mesmo tempo sucumbir a seu tormento e gerar o poema. A aproximação do poetar ao partejar é imagem já antiga, um dos lugares comuns dos depoimentos sobre criação poética, mas aqui o conjunto é revestido de tal intensidade sonoro-imagética que se renova e põe em relevo o lado tormentoso do fazer poético.

\footnotetext{
Trabalha naquilo antigo enquanto o mundo se move para o centro de si mesmo, como se todos os pontos em que trabalhas fossem o centro do mundo.
}

A segunda estrofe contrasta com a primeira: é curta e pedagógica. O outro continua a aconselhar o sujeito poético a prospectar o passado no presente móvel, numa imagem poderosa de convergência e divergência, defendendo a tese de que a poesia não pode se afastar da história, antiga e atual, nem pode desconsiderar qualquer tema, pois todos atingem o mundo, matéria do poético. Há um jogo sonoro entre trabalho, centro e ponto, que enfatiza o refluxo em espiral da imagem - hipnótica - no seu todo.

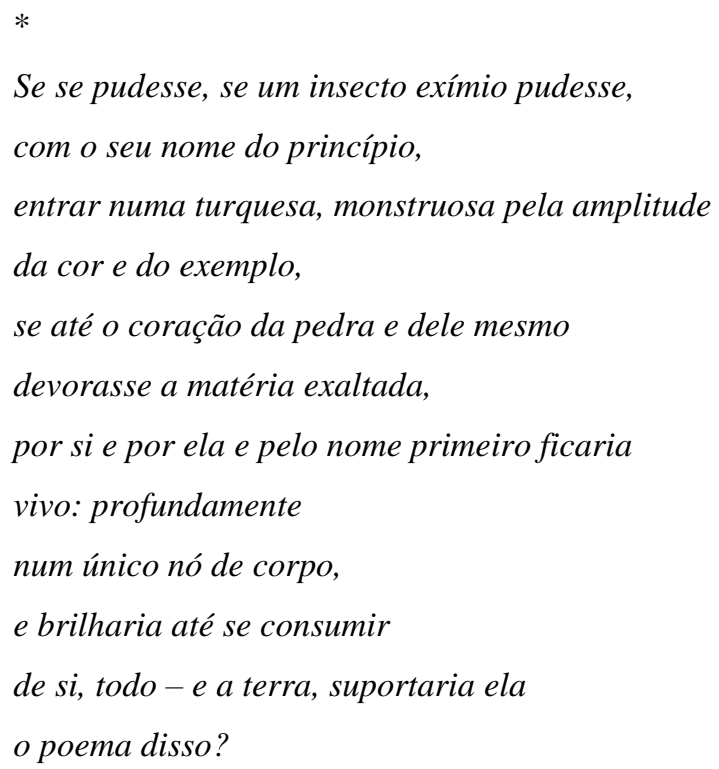

A próxima estrofe inventa outra imagem para o abismo cósmico da primeira. Penetrar na turquesa qual inseto "exímio" e devorar seu núcleo, sendo simultaneamente por ele devorado, retoma, ao contrário, a imagem da poesia como luz insuportável, desta vez 
materializada na pedra preciosa, somada à de "plutônio", cujo brilho de prata e efeito destruidor é transferido para o corpo, consumindo-o. Corpo reduzido a "nó" evoca por metonímia os "sacos de sangue amarrado". O desaparecimento do inseto-poeta, brilhando até se extinguir, determinado pela poesia da turquesa desmesurada, reduzindo-o a um nome-nó, elevaria o poema à altura incomensurável da poesia, mas não estaria ele acima dos extremos que o mundo poderia suportar? A cena cósmica da primeira estrofe aqui se intensifica a ponto de levantar a hipótese de que a "alta" poesia seria algo impossível de ser apreendido.

Sou eu, assimétrico, artesão, anterior

-- na infância, no inferno.

Desarrumado num retrato em ouro todo aberto.

A luz apoia-se nos planos de ar e água sobrepostos,

e entre eles desenvolvem-se

as matérias.

Na última estrofe, o sujeito poético assume seu "eu" terreno, definido como artesanal, "desarrumado", situado entre ar e água, batido pela luz, à mercê das "matérias" que lhe aparecem independentes de seu labor. Dois lugares se impõem em termos de sua condição: "inferno" e "retrato", a ele, que está "na infância", ou seja, é apenas um iniciado. Seu "eu" anterior perpassa não só o "inferno" antes aludido, mas também o (auto) retrato "em ouro todo aberto", mas os sons sibilantes e dentais, fricativos e nasais, que se alternam numa melodia assimétrica, unificada pelos "ee", em que os "pp" de "apoia-se", "planos" e "sobrepostos”, mais plosivos, dão a sensação de deslocamento, de estar fora de lugar.

Trabalho um nome, o meu nome, a dor do sangue,

defronte

da massa inóspita ou da massa

mansa de outros nomes.

Vinhos enxameados, copos, facas, frutos opacos, leves

nomes,

escrevem-nos os dedos ferozes no papel

pouco, próximo. Tudo se purifica: o mundo

e o seu vocabulário. No retrato e no rosto, nas idades em que,

gramatical, carnalmente, me reparto. 
Confrontado com "as matérias", o "eu" dedica-se ao seu nome, "a dor do sangue" dentre os outros nomes, mansos ou inóspitos. A enumeração de objetos que poderiam compor uma natureza morta dá vez à escrita, "feroz", purificadora das coisas do mundo e de seus nomes. $\mathrm{O}$ "eu" cindido entre o pronome pessoal e o corpo, também se purifica no retrato e no tempo, na eclosão do poema. A melodia alterna "aa", "oo" e "ee" com consoantes fortes e suaves, num ritmo que utiliza pausas estratégicas em "defronte", "massa/mansa" "nomes", "pouco, próximo", "mundo" "em que", acentuando os inícios dos versos que os seguem, superando a fragmentação com uma levada descendente, anticlimática, que deságua tranquila em "me reparto". O trabalho poético, que exige artesanato exímio, bem como sofrimento da alma, finalmente constrói o poema.

Desequilibro-me para o lado onde trabalha a morte.

O lado em como isto se cala.

Entretanto, a assimetria e o desarranjo do corpo, vencidos pela ferocidade dos dedos que escrevem, colocam o poeta às margens da aniquilação, aquele abismo profundo do início, onde tudo "se cala", onde as palavras ainda não são. É ali que pulsa o poético.

Maria Lúcia Dal Farra (Posfacial, in HELDER, 2009, p. 149), comentando a poesia de Helder, enfatiza seu caráter de "aventura que opera sobre o imaginário a ponto de conduzir a realidade até o enigma, abrindo-a em decifrações cada vez mais problemáticas". Observando que o poeta revela uma desconfiança quanto ao que seria o real - outra posição cara aos pósmodernos - salienta que ele "construiu para si, a partir de tal suspeita, uma maneira absolutamente rigorosa de dizer o arbitrário, um jeito de fazer cada palavra ser, com segurança, outra coisa que não ela" (p. 150).

A poesia sobre a poesia, em Helder, manifesta essa descrença na relação palavra-coisa, paradoxalmente extraindo da palavra tudo o que de genesíaco poderia haver nela, desordenando-a em sons, ritmos, sintaxes, sentidos, beirando perigosamente o caos, para restituí-la em sua força irreprimível de significação, não dissociada do real, mas instituindo, também nele, o vórtice da incerteza. Se aqui o real é a poesia, o poema a empurra para a margem do abismo, levando consigo o sujeito poético na vertigem de uma atividade criadora insubmissa e passionalmente insatisfeita. 


\section{REFERÊNCIAS}

AMARAL, Fernando Pinto do. O mosaico fluido: modernidade e pós-modernidade na poesia portuguesa mais recente. Lisboa: Assírio \& Alvim, 1991.

DAL FARRA, Maria Lúcia. Posfacial. In: HELDER, Herberto. O corpo o luxo a obra. São Paulo: Iluminuras, 2009.

HELDER, Herberto. O corpo o luxo a obra. São Paulo: Iluminuras, 2009.

HUTCHEON, Linda. Poética do pós-modernismo: história, teoria, ficção. Rio de Janeiro: Imago, 1991.

MARINHO, Maria de Fátima. Herberto Helder: a obra e o homem. Lisboa: Arcádia, 1982.

MARTINHO, Fernando J.P. Depois do modernismo, o quê? - o caso da poesia portuguesa. Revista Semear, Cátedra Padre António Vieira de Estudos Portugueses, PUC-Rio, Rio de Janeiro, n. 4, online. 